\title{
Meningkatkan Penampilan Broiler dengan Pemacu Pertumbuhan Alami
}

\section{Enhance Broiler Appearance with Natural Growth Boosters}

\author{
A A Candra ${ }^{1 *}$ dan K Magfiroh ${ }^{1}$, \\ ${ }^{1}$ Jurusan Peternakan, Politeknik Negeri Lampung \\ *E-mail korespondensi: adicandra@polinela.ac.id
}

\begin{abstract}
The study aims to determine the effect of the addition of probiotics, prebiotics and eubiotics in broilers on the appearance of broiler production. The material used was 100 broilers, which were kept from Day Old Chicks until the age of 4 weeks and distributed in 4 groups, namely probiotics, prebiotics and eubiotics. The research method was experimental compiled based on a Completely Randomized Design (CRD) with 4 treatments and 5 replications. The treatments tested were as follows: the control group (without any additions), probiotics, prebiotics and eubiotics. The variables observed in this study were feed consumption; weight gain (PBB); feed conversion; carcass weight and mortality. The data obtained were analyzed using analysis of variance and if there were differences between treatments. The results showed that the addition of probiotics, prebiotics and eubiotics increased weight gain, increased consumption and was able to suppress the value of feed conversion.
\end{abstract}

Keywords: Broiler, Appearanc, Growth Boosters

Diterima: $\quad$ Disetujui:

\section{PENDAHULUAN}

Ayam pedaging merupakan salah satu sumber protein hewani yang murah, dibanding dengan daging sapi atau kambing. Keunggulan ayam pedaging adalah pertumbuhannya yang sangat cepat, sehingga dapat dijual sebelum usia 5 minggu, dengan bobot rata-rata $1,5 \mathrm{~kg}$. Ayam pedaging sangat efisien dalam merubah pakan menjadi daging. Pakan merupakan faktor yang sangat berpengaruh dalam menentukan keberhasilan pemeliharaan ayam, khususnya ayam pedaging. Biaya pakan mencapai $60-70 \%$ dari total biaya produksi dan meningkatkan efisiensi protein.

Penggunaan bahan pakan lokal menjadi alternatif untuk menekan biaya produksi. Bahan pakan lokal yang digunakan tentunya harus memiliki beberapa fungsi pakan yaitu memiliki kandungan gizi yang dibutuhkan oleh ternak, murah serta mudah didapat. Kandungan gizi utama yang berperan penting bagi pertumbuhan ayam pedaging adalah protein, energi (karbohidrat dan lemak), vitamin, mineral serta air. Salah satu feed additive pakan yang dapat digunakan untuk mencapai produktivitas yang optimal dan efisien adalah dengan memberikan probiotik. Probiotik adalah jasad renik nonpatogen yang apabila dikonsumsi dalam jumlah cukup dapat memberi manfaat bagi kesehatan dan fisiologi tubuh (Anonim, 2002). Probiotik akan mempengaruhi fungsi fisiologi usus secara langsung maupun secara tidak langsung dengan cara memodulasi mikroflora usus dan sistem imun mukosa terutama mukosa saluran cerna. Saat ini telah beredar produk probiotik yang mengandung mikroba lipolayam pedaging, selulolayam pedaging, lignolayam pedaging, dan mikroba asam lambung. Suplemen berbagai biakan mikroba probiotik pada ayam seperti Lactobacillus (Johnson et al, 1986, Bacillus spp (Jin et all, 1998) mempunyai dampak positif terhadap 
penampilan ayam seperti pertumbuhan, produksi telur dan efisiensi penggunaan pakan. Probiotik mempunyai beberapa pengaruh yang positif bagi kesehatan, diantaranya hipokolesterolemik, yaitu menurunkan konsentrasi kolesterol serum darah baik pada manusia maupun pada ternak (Rodas et al, 1996). Bakteri probiotik merupakan bakteri yang dalam keadaan hidup dikonsumsi oleh hewan dan manusia dan dapat menimbulkan efek kesehatan bagi inangnya. Probiotik diketahui mempunyai beberapa keunggulan, terutama adalah kemampuannya dalam menghasilkan senyawa antimikroba yang dapat membunuh atau menghambat pertumbuhan bakteri patogen. Efektivitas antimikroba probiotik sangat spesifik tergantung dari strainnya

Penelitian bertujuan mengetahui pengaruh penambahan probiotik, prebiotic dan eubiotik pada ayam pedaging terhadap penampilan produksi ayam pedaging. Manfaat penelitian ini adalah informasi ilmiah dalam penggunaan probiotik, prebiotic dan eubiotik untuk peningkatan penampilan produksi ayam pedaging.

\section{MATERI DAN METODE}

Materi yang digunakan adalah 100 ekor ayam pedaging, yang dipelihara sejak Day Old Chicks sampai umur 4 minggu dan didistribusikan dalam 4 kelompok, yaitu probiotik, prebiotic dan eubiotik.

Metode penelitian adalah eksperimental disusun berdasarkan Rancangan Acak Lengkap (RAL) dengan 4 perlakuan dan 5 ulangan. Perlakuan yang di ji adalah sebagai berikut yaitu kelompok control (tanpa penambahan apapun), probiotik, prebiotic dan eubiotik. Peubah yang diamati dalam penelitian ini adalah konsumsi pakan; pertambahan berat badan

(PBB); konversi pakan; berat karkas, karkas dan mortalitas. Data yang diperoleh dianalisis dengan penggunakan analisis sidik ragam dan jika terdapat perbedaan antara perlakuan diuji dengan uji jarak berganda Duncan..

\section{HASIL DAN PEMBAHASAN}

Hasil pengamatan pengaruh pemberian probiotik dalam pakan terhadap penampilan produksi ayam pedaging tertera pada Tabel 1.

Tabel 1. Pengaruh Perlakuan terhadap Penampilan Produksi Ayam Pedaging

\begin{tabular}{lrrrr}
\hline \multicolumn{1}{c}{ Variabel/kelompok } & \multicolumn{1}{c}{ Kontrol } & \multicolumn{1}{c}{ Probiotik } & \multicolumn{1}{c}{ Eubiotik } & \multicolumn{1}{c}{ Prebiotik } \\
\hline PBB (g/ekor) & 1399 & 1322,6 & 1400,4 & 1402,78 \\
Konsumsi (g/ekor) & 1487,9 & 1489,7 & 1492,1 & 1487,8 \\
FCR & 1,07 & 1,13 & 1,06 & 1,06 \\
Bobot Hidup (g/ekor) & 1099,5 & 1800,5 & 1519,5 & 1475,5 \\
Bobot Karkas (g/ekor) & 980 & 1349,5 & 944,5 & 1105 \\
Persentase karkas (\%) & 89,13 & 74,95 & 62,15 & 74,88 \\
\hline
\end{tabular}


Hasil penelitian menunjukkan konsumsi pakan ayam pedaging pada pemberian eubiotik memberikan konsumsi tertingggi sebesar 1.492 gram diikuti perlakuan pemberian prebiotik, probiotik, dan kontrol. Hasil pertambahan bobot badan pada perlakuan selama 4 minggu memperlihatkan bahwa pertambahan bobot badan tertinggi terjadi pada ayam yang diberikan prebiotik, dilanjutkan eubiotik dan probiotik. Hal ini menunjukkan bahwa pemberian zat tersebut memberikan kontribusi pada pertambahan bobot badan ayam broiler. Hal serupa juga ditunjukkan dengan kemampuan ayam dalam mengkoversi pakan menjadi daging, Nampak bahwa pemberian prebiotik, eubiotik mampu menekan nilai feed convertion ratio dibanding kontrol. Bila ditilik dari penampilan karakas didapatkan bahwa persentase karkas kelompok ayam yang diberikan perlakuan memiliki nilai lebih kecil dibandingkan kontrol. Hal ini mengindikasikan pemberian perlakuan tidak berefek langsung pada nilai persentase karkas.

Penambahan probiotik bekerja dengan baik pada saluran pencernaan ayam sehingga konsumsi pakannya menjadi lebih rendah. Hal ini di sebabkan meningkatnya konsentrasi probiotik yang ditambahkan. Semakin tinggi konsentrasi probiotik yang diberikan maka semakin tinggi bakteri yang terkandung di dalamnya maka ternak akan semakin efisien dalam mengkonsumsi pakan. Hal ini karena terjadi penambahan jumlah populasi mikroba yang menguntungkan bagi ternak, mencegah berkembangnya mikroba yang merugikan dalam saluran pencernaan sehingga dapat meningkatkan pencernaan makanan, dengan demikian pemberian probiotik dapat mengefisienkan konsumsi pakan.

Menurut Bel dan Weaver ( 2002) faktor utama yang memengaruhi konsumsi pakan adalah kandungan energi pakan, temperatur, dan jumlah pakan yang diberikan. Probiotik dapat memperbaiki saluran pencernaan dan meningkatkan kecernaan pakan, yaitu dengan cara menekan bakteri patogen dalam saluran pencernaan sehingga mendukung perkembangan bakteri yang menguntungkan yang membantu penyerapan zat-zat makanan (Kompiang, 2002). Probiotik dapat mengubah pergerakan mucin dan populasi mikroba didalam usus halus ayam, sehingga keberadaannya dapat meningkatkan fungsi dan kesehatan usus, memperbaiki komposisi mikroflora pada sekum, serta meningkatkan penyerapan zat makanan (Mountzouris, 2010).

Pertambahan berat badan menunjukan bahwa pakan yang dikonsumsi oleh ayam cukup efisien dan banyak digunakan untuk pertumbuhan. Jika ayam mengkonsumsi pakan dalam jumlah yang banyak namun pertambahan berat badan tidak tinggi maka diduga penyerapan makanan dalam saluran pencernaan ayam tersebut berlangsung tidak sempurna. Selain itu bisa juga karena ayam sedang berada dalam kondisi sakit, faktor lainnya adalah jenis kelamin, suhu dan kualitas makanan. Pertambahan berat badan ini sejalan dengan konsumsi pakan yang menunjukkan perbedaan pengaruh yang sangat nyata. Yeo, J. dan K. Kim (1997) menyatakan bahwa penambahan kultur probiotik pada pakan ayam mempunyai dampak positif terhadap pertumbuhan, produksi telur dan efisiensi penggunaan pakan.

Probiotik meningkatkan aktivitas enzim pencernaan sehingga penguraian dan penyerapan makanan menjadi lebih sempurna sehingga makanan yang diserap dengan baik tersebut dapat dimanfaatkan oleh ayam untuk pertumbuhan jaringan dan peningkatan berat badan. Probiotik cair berperan dalam memperbaiki serapan nutrisi pada ayam. Hal ini diduga karena kandungan mikroorganisme pada probiotik cair bekerja secara sempurna didalam saluran pencernaan sehingga berpengaruh pada semua perlakuan. Selain itu kondisi dan dinamika populasi mikroflora dalam saluran cerna hewan ternak sangatlah kompleks dan bervariasi dari waktu ke waktu tergantung pada spesies, umur, kondisi umum dan tipe ternak tersebut (Jin, L. Z., Y. W. Ho, N. Abdullah and S. Jalaludin, 1998).

Gsianturi (2002) menyatakan bahwa bakteri yang terdapat dalam probiotik berperan meningkatkan produk metabolisme yang bermanfaat bagi tubuh ternak. Produk metabolisme tersebut dapat dimanfaatkan secara maksimal untuk membentuk atau menambah ukuran jaringan baru. Hasil dari pertumbuhan ataupun perkembangan jaringan baru tersebut berpengaruh terhadap kenaikan berat badan ayam pedaging. Jin el at, 1998), menyatakan bahwa pemberian biakan Bacillus spp. dalam pakan memberikan hasil positif terhadap pertumbuhan ayam pedaging. 
Kompiang (2009) menjelaskan bahwa probiotik meningkatkan aktivitas enzim pencernaan sehingga penyerapan makanan menjadi lebih sempurna dengan makin luasnya area absorpsi sebab probiotik dapat mempengaruhi anatomi usus yaitu villi usus menjadi lebih panjang dan densitasnya lebih padat. Di mana proses absorpsi hasil pencernaan terjadi di permukaan vili yang memiliki banyak mikrovili. Jin et all, 1997) menyatakan bahwa keberadaan probiotik dalam pakan dapat meningkatkan aktivitas enzimatis dan meningkatkan aktivitas pencernaan. Akibatnya, zat nutrisi seperti lemak, protein, dan karbohidrat yang biasanya banyak terbuang dalam feses akan menjadi berkurang.

Konversi pakan merupakan perbandingan antara konsumsi pakan dengan pertambahan berat badan setiap minggu dalam satu periode produksi. Konversi pakan melibatkan pertumbuhan ayam dan konsumsi pakan. Pertumbuhan yang cepat dengan jumlah konsumsi pakan yang sedikit menunjukkan efisiensi penggunaan pakan yang tinggi. Konversi pakan merupakan salah satu indikator keberhasilan usaha bagi perternak. Perbandingan konsumsi pakan dan pertambahan berat badan akan menghasilkan angka sebagai dasar perhitungan ekonomis.Hasil ini sejalan dengan berpengaruhnya pemberian probiotik terhadap konsumsi pakan dan pertambahan berat badan. Adanya pengaruh ini karena bekerjanya probiotik secara efisien. Menurut Rodas et al., (1996) bahwa efisiensi penggunaan pakan berpengaruh nyata apabila probiotik ditambahkan dalam pakan yang cukup seimbang komposisi dan nutrisinya.

\section{KESIMPULAN}

Penambahan probiotik, prebiotik dan eubiotik meningkatkan pertambahan berat badan, dan meningkatkan konsumsi serta mampu menekan nilai konversi ransum.

\section{UCAPAN TERIMA KASIH}

Penelitian ini didanai oleh DIPA Politeknik Negeri Lampung tahun 2018

\section{DAFTAR PUSTAKA}

Anonim, 2002, Food and Agriculture Organization of United Nation and World Health Organization. posting date. Guidelines for the evaluation of probiotics in food. Food and Agriculture Organization of United Nation and World Health Organization United Nation and World Health Organizationworking Group Report.

Bell, D.D and W. D. Weaver., 2002. Commercial Chicken Meat and Egg Production.4th Ed. Kluver Academic Publishers. USA.

G Sianturi., 2002. Probiotik dan prebiotik untuk kesehatan. http://www.gizi.net/arsip/arc0-2002.html - 26k. [25 September, 2018]

Jin, J.Z., Ho. Y.W., Abdullah, N., Ali M.A and Jalaludin, S., 1998. Effect of adherent Lactobacillus cultures on growth, weight of organs and intestinal micloflora and volatile fatty acids in broiler. Anim Feed Sci. Tech. 70(3):197-209.

Jin, L. Z., Y. W. Ho, N. Abdullah and S. Jalaludin. 1998. Growth Performance,Intestinal Microbial Populations, and Serum Cholesterol of Broilers Fed Diets Containing Lactobacillus Cultures. Poultry Science. 77: 1259-1265.

Jin, L. Z., Y. W. Ho, N. Abdullah and S. Jalaludin., 1997. Probiotic in Poultry: Modes of Action. Worlds Poultry Science Journal. 53(4): $351-368$.

Johnson, I.T., Gee J.M., Price K., Curl, C, and Fenwick G.R., 1986. Influence of saponims on gut permeability and active native transport in vitro. J Nutr : 2270-2277 
Kompiang, I. P., 2009. Pemanfaatan Mikroorganisme sebagai Probiotik untuk Meningkatkan Produksi Ternak Unggas di Indonesia. Pengembangan Inovasi Pertanian. 2(3): 177-191.

Kompiang, I.P. 2002. Pengaruh ragi: SaccharomycesCerevisiae dan ragi laut sebagai Pakan Imbuhan Probiotik terhadap kinerja unggas. JITV 7(1):18-21.

Mountzouris. K., C. P. Tsitrsikos, I. Palamidi., A. Arvaniti., M. Mohnl., G. Schatzmayr and K. Fegeros. 2010. Effects of probiotik inclusion levels in broiler nutrion on growth performance, nutrient digestibility, plasma immunoglobulins, and cecal micrroflora compostion. Poult. Sci. 89:58-67

Rodas B.Z., S.E . Gilliland S.E., and C. V. Maxwell., 1996.Hypocholesterolemic action of L. Acidophilus ATCC 43121 and calcium in swine with hypercholesterolemia induced by diet. J Dairy Sci 79:21212128

Yeo, J. dan K. Kim, 1997. Effect of Feeding Diets Containing an Antibiotic, a Probiotic, or Yucca Extract on Growth and Intestinal Urease Activity in Broiler Chicks. Poultry Science. 76: 381-385. 